\title{
Determinants of customers' adoption of mobile banking in Tanzania: Further evidence from a diffusion of innovation theory
}

\section{Neema Mori ${ }^{1}$ iD, Rosallia Mlambiti²}

\begin{abstract}
The main goal of this study was to examine the influence of demographic factors on the adoption of innovative mobile banking services in Tanzania. It utilized Rogers' Diffusion of Innovation Theory (DIT) to ascertain the importance of situation-based demographic factors. A survey was conducted with 416 customers of a leading bank in Tanzania. The study applied self-administered questionnaires completed by the respondents who had agreed to participate. The data were analyzed using a combination of descriptive and multivariate analyses. The descriptive results revealed that the majority of respondents used mobile banking once to three times a week to check their balance, download a mini-statement, pay different bills, transfer funds from their account to a mobile telecom network, and buy airtime. The regression results further showed a positive and significant relationship between level of income and education attainment on the one hand and the adoption of mobile banking on the other. The study argues that promotional practices and awareness-raising campaigns are needed to capture the demographic profiles of customers in order to encourage them to adopt mobile banking. Theoretically, the study has shown the relevance of applying the situation-based theory to the adoption of innovative technologies as regards banking services in Tanzania. It also broadens our understanding of the importance of demographic factors that have received little attention from the dominant socio-psychological theories.
\end{abstract}

Keywords: mobile banking, Tanzania, income level, gender, age, education

1 Neema Mori, Ph.D., University of Dar es Salaam Business School, University of Dar es Salaam, Tanzania and Norwegian Centre for Microfinance Research, University of Agder, Boks 422, 4604 Kristansand, Norway, e-mail: neema.mori@gmail. com (ORCID ID: https://orcid.org/0000-0002-2119-2000).

2 Rosallia Mlambiti, CRDB Bank Plc., e-mail: rossallia.mlambiti@crdbbank.com 


\section{INTRODUCTION}

Digitalization, increasing business competition, and innovation have revolutionized the banking services landscape, resulting in a shift from traditional face-to-face encounters to technology-based ones, thereby increasing efficiency and reducing costs (Ajide, 2016; Gosavi, 2017). This change has led to the introduction of mobile banking services, which provide an opportunity to operate virtual bank accounts and transactions through the Internet and mobile phones (Masamila, 2014; Singh \& Srivastava, 2018). As this is an innovation, the adoption of it, especially in sub-Saharan Africa, has been slow. Thus, ascertaining the adoption of mobile banking, which means customers' acceptance and use of mobile terminals (Alalwan, Rana, Dwivedi, Lai, \& Williams, 2015) is critical for the banking sector. Recent studies revealed that the number of customers who preferred mobile banking to incumbent forms doubled from 2008 to 2012 (Reem \& Jawdat, 2018).

With the growing use of mobile phones in sub-Sahara Africa, in general, banks have the great potential to offer mobile banking services to the majority of people. However, only a few of those living in remote villages have computers connected to the Internet, and poor infrastructure does not support mobile banking (Abdinoor \& Mbamba, 2017; Cruz, Neto, Gallego, \& Laukkanen, 2010). However, mobile banking is advantageous as it saves time and money, is convenient, and provides customers with independence and promptness (Ajide, 2016).

The adoption of mobile banking may be related to the increased number of mobile phone and internet users (Swai, 2015), although that is not the only factor. Previous research has mainly focused on functional and socio-psychological perspectives, such as the theory of planned behavior, the technology adoption model, and social exchange theory (Venkatesh et al., 2003; Curran \& Meuter, 2005; Zhou, Lu, \& Wang, 2010). These studies indicated the adoption of mobile banking could be influenced by customers' perceptions of and attitudes to various dimensions of the service, such as quality, security, accessibility, performance, social influence, affordability, convenience, price, comparative advantage and the associated risks (Abdinoor \& Mbamba, 2017; Curran \& Meuter, 2005, Yu, 2012). Although the influence of customers' socio-economic situation, especially their demographic characteristics, has been acknowledged by researchers (Yu, 2012; Swai, 2015), it has not been given much attention.

Diffusion of innovation theory posits three significant strands of influence: attributes of innovation, the innovation-decision process, and adopter categories (Grgurović, 2014). Rogers (2003) further describes five adopter categories based on the time when the individual adopts an 
innovation: innovators, early adopters, early majority, late majority, and laggards. This study uses these categories to examine the relationship between the demographics of the individual and the subsequent ability to adopt innovative solutions, in this case, mobile banking. Hence our research question is as follows:

$R Q$ : What is the relationship between customers' demographics (level of income, gender, education, and age) and the adoption of innovative mobile banking services offered by commercial banks in an emerging economy?

According to Bhatt and Bhatt (2016), knowing about how customers' demographics relate to their adoption of mobile banking can provide an in-depth understanding of their use of mobile banking, thereby helping alternative strategies to be designed that will foster adoption. In addition, demographic factors relate to the adopters' categories, which can shape the innovation-decision process and its outcome (Grgurovic, 2014).

It would be particularly interesting to study these factors with cases from the East African region, where people have relatively low incomes and education levels, and being either female or male can impact how people engage with innovation and technological advances (Swai, 2015).

This study used customers of one of the largest banks in Tanzania as its context. This bank is known as one of the innovative banks in the country and has the largest number of customers. Customers who use mobile banking can transfer funds to other banks, mobile phones, pay utility bills, purchase airtime for themselves and others, send money to people with no bank accounts or ATM card, check their balance, register online on their mobile phone, and obtain a mini-statement and transaction alerts.

We used the adopter categories of Diffusion of Innovation Theory (DIT) to develop and test the hypotheses based on each demographic factor. Our study comprised of 416 customers. The data were analyzed using a combination of descriptive and multivariate analyses. The descriptive results show that the majority of respondents used Mobile banking once to three times a week to conduct various transactions. The regression results show that there is a positive and statistically significant relationship between income level and adoption of mobile banking. Indeed, the higher the income, the more likely a person will adopt mobile banking. A positive and significant relationship was also revealed between education attainment and adoption of mobile banking. However, although it was revealed that age was not important in determining adoption, it was found to cause a positive relationship with the adoption of mobile banking. Thus, given the accessibility of banking services 
and the level of infrastructure, the older a person becomes, the more likely she or he will use mobile banking.

We contribute to a deeper understanding of mobile banking adoption by responding to calls for further investigation into the influence of customers' situational factors, especially the demographic characteristics of individuals in emerging markets (Swai, 2015). In addition, through the use of Rogers' (1995) DIT, the findings broaden our understanding of the importance of situational factors on mobile banking use in general, as well as the importance of demographic factors that have received limited attention by the dominant socio-psychological theories. From the practical point-of-view, the findings of this study provide bank managers with crucial information that will enable them to conduct appropriate marketing campaigns and customize mobile banking options to cater to specific demographic segments.

The rest of the paper is organized as follows. Section 2 presents the theory and literature review, followed by section 3 that describes the methodology. Section 4 presents the findings and discussion, while section 5 provides the conclusion.

\section{LITERATURE REVIEW}

\section{Diffusion of Innovation Theory (DIT)}

Diffusion of Innovation Theory (DIT) is considered one of the most appropriate theories for understanding the issue of the adoption of innovation and new technologies. According to Rogers (1995), an innovation is an idea, practice, or object that has distinguishable features perceived to be new. Diffusion is a process by which that innovation is communicated through specific channels over time among the members of a social system. For the purpose of this study, mobile banking is considered to be such innovation, while a bank is considered a channel through which that innovation is being communicated.

The theory further suggests five stages through which the individual can progress from the first contact with innovation to the adoption stage (Rogers, 2003). The first stage is knowledge when the individual is exposed to innovation and learns about its purpose and function. The second stage is persuasion, whereby individuals form positive or negative opinions about the innovation, which may influence the individual to adopt or not to adopt the innovation. The resulting decision to adopt the innovation is made in stage three, the decision stage, whereby before deciding, individuals may try the innovation out to see its usefulness in their setting. The fourth stage is implementation when the individual has decided to use the innovation. 
Finally, if satisfied, the final stage of confirmation is attained whereby the innovation becomes wholly integrated into the ongoing routine, and the adopter may start promoting the innovation to others (Grgurovic, 2014). Each of these stages is critical and interacts with the characteristics of a person.

Because of the importance of these stages, Rogers (2003) further investigates and discusses five characteristics of adopters likely to accept innovative technology. He identified five (5) clusters of adopters of new technology, which varied according to the time the new product was adopted during its life cycle. These groups are: innovators, early adopters, early majority, late majority, and laggards (Rambocas \& Arjoon, 2012). Each cluster differs according to the rate of adopting innovative technology. The first group, labeled as "innovators," represents a group of customers that exercise tremendous eagerness and thirst for new ideas. The second cluster is "early adopters" who follow innovators in their adoption and do so relatively early in the product's life cycle. The third group of customers, the "early majority," first collects more information on products and services before adoption. Their tendency to adopt is highly dependent on recommendations and suggestions made by early adopters or opinion leaders. However, the "late majority" group adopts only after the product has been tried by other groups and proven to be successful. Lastly, "laggards," who are often suspicions about new products, are frequently alienated by rapidly advancing societies (Grgurovic, 2014).

The theory further posits that certain variables are associated with an individual's adoption of an innovation and their association with these clusters. These variables, among others, include age, gender, education, and income (Rogers, 1995). DIT assumes that these demographic variables are related to an individual's response to innovation, thereby affecting the rate of adoption and the diffusion of the innovation. For example, according to the theory, young male high-income earners and literate individuals with more years of education are likely to belong to the first clusters of adopters compared to their counterparts (Rogers, 1995). The theory assumes that members of the former category have a greater awareness, as well as the resources and courage to take risks by engaging with a new phenomenon such as innovation.

DIT, with its assumptions, has been criticized for being linear and ignoring an individual's context when adopting an innovation (van de Wijngaert and Bouwman, 2009). However, DIT and its concept of early adopters and laggards, as well as its assumptions on the influence of demographics, remains the bedrock on which much research is based. Innovation further determines the standards and directions of development of a firm, and consequently, on its development and competitive advantage (Golejewska, 2018). Because of its focus, this theory helps us understand the extent to which the demographics 
of bank customers can influence the ease with which they adopt the new technology of mobile banking as a complement to traditional banking.

\section{Hypotheses development}

\section{Income level}

Level of income refers to an individual's state of earning with reference to money measured either per month or year (Munisi, 2015). Several studies have stated that income level is an essential factor that has a strong influence on adoption level (Sulaiman, Jaafar, \& Mohezar, 2007). This is because higherincome earners are often associated with possessing a computer and having access to the internet and a mobile phone (Lohse, Bellman, \& Johnson, 2000). Harma and Dubey (2009) clarified that people who work in a good, well-paid profession do not perceive mobile banking to be risky, unlike other customers. According to Rogers (1995), younger people with a high level of income are the early adopters of mobile- banking. A study in the United States of America (USA) found that income level has a positive impact on adoption level (Kolodinsky, Hogarth, \& Hilgert, 2004).

Similarly, Lee, Lee, and Kim (2007) found that income level has a positive influence on the adoption of internet banking. Mattila (2003) further found that having a high income poses a significant and positive effect on the adoption of internet banking. With regard to DIT, early adopters of an innovation are more likely to be high-income earners than late adopters. A number of studies (such as Lohse et al., 2000; Sulaiman et al., 2007) supported this assumption. Mattila (2003) found that having a high income has a significant and positive effect on the adoption of internet banking. From these arguments it is hypothesized that:

H1: There is a positive relationship between customers' income level and the adoption of mobile banking.

\section{Gender}

Gender refers to an individual's identification in terms of sexual status, i.e. male or female (Munisi, 2015). According to Laforet and Li (2005), males are more interested in using various types of technology than females. Venkatesh and Morris (2000) found that gender is an important determinant of technology adoption and usage in Germany and the UK, in that males are more likely than females to adopt new technology. Regarding online shopping, Monsuwe, Dellaert, and de Ruyter (2004) found that males are 
more positive about shopping online, whereas females prefer the traditional way of shopping or by catalog. Similarly, in Iran, Mirza, Beheshti, Wallstrom, and Mirza (2009) found that internet banking is used much more by males than females. Sulaiman et al. (2007) found that $70 \%$ of males in Malaysia use mobile banking, as opposed to $34.4 \%$ of females. Alafeef, Singh, and Ahmad (2011) found that the percentage of male Jordanian Internet users is higher than that of females, as males are willing to take higher risks and are keener than women to try out new technological products. However, DeBaillon and Rockwell (2005) found an insignificant relationship between gender and the adoption of internet banking. With reference to Tanzania, the relationship may be significant because of longstanding cultural traditions and entrenched social norms that distinctly define gender roles. For example, there is a division of labor between males and females in Tanzania (Krogh, Hansen, Wendt, \& Elkjaer, 2009). Females have, traditionally, not adequately participated in the Tanzanian workforce (Krogh et al., 2009), and so it might be difficult for females to adopt different types of technology. Unfortunately, there is limited gender-disaggregated evidence on the adoption of innovation from the point-of-view of mobile banking in emerging economies, and therefore the paper hypothesizes that:

H2: Male customers are positively associated with the adoption of mobile banking.

\section{Education}

Education refers to an individual's status in terms of her or his attainment of systematic or formal instruction at school, college, or university (Munisi, 2015). Studies have approached the education variable in terms of the number of years spent in education and level of education. Concerning the number of years, Burgess (1986) argued that individuals with more years of education are more likely to be in high-status occupations, and so are more likely to adopt new technology. These findings indicate a relatively positive relationship between education and the adoption of mobile banking technology.

With reference to the level of education, researchers have put it into four categories: university degree or above, diploma/higher diploma, secondary education, and primary education. Several prior studies found a positive relationship between the level of education and the adoption of mobile banking. Hill (1998) found that level of education is an essential factor influencing the adoption of new technologies because education is correlated with an individual's level of internet literacy. This means that those who have received formal instruction at school, college, or university are much more 
likely to embrace new technologies. Most schools, colleges and universities today teach computer skills as a compulsory part of the curriculum. The level of education is most important for improving one's social standing in African and Arab countries. Harma and Dubey (2009) found that customers who are less educated are significantly more opposed to banking innovations than other members of a social system.

Ahmed, Moreton, Mehdi, and Elmaghraby (2013) indicated that the high rate of illiteracy has greatly hindered the implementation of e-commerce in Libya. Sulaiman et al. (2007) revealed that $75 \%$ of adopters have a high level of education (university level). DIT states that early adopters of an innovation are more likely to be literate, with more years of education than late adopters (Rogers, 2003). However, in emerging economies such as Tanzania, there are not many individuals with a university degree (Mori, 2014). In this context, the potential users of mobile banking will be expected to have secondary education and above. It is, therefore, interesting not only to investigate the influence of education in terms of the number of years in school but also the level and type of education, especially in a context of Tanzania. Therefore:

H3: There is a positive relationship between education attainment and the adoption of mobile banking.

\section{Age}

Age refers to the length of time that a person has lived, frequently expressed in terms of the number of years (Munisi, 2015). Past research has noticed the influence of age on the adoption of mobile banking. Wood (2002) found that younger adults under 25 are more interested in adopting new technology than older customers. Similarly, Mattila, Karjaluoto, and Pento (2003) found that the majority of internet banking users are middle-aged, ranging from 25 to 34 years old, whereas non-users were older. Venkatesh and Morris (2000) asserted the importance of understanding the age difference in the adoption of new technology. Sulaiman et al. (2007) found that mobile banking in Malaysia is more prevalent among younger customers. Also, Harma and Dubey (2009) found that younger people do not perceive mobile banking to be risky, unlike older customers.

In the Middle East, especially in Saudi Arabia, the factor of age was important in influencing differences in the adoption of information technology, because the population of Saudi Arabia is relatively young. Younger people were also found to help Arab organizations to introduce and adopt new technologies. The majority of potential users of mobile banking are between 17 and 35 years old in Jordan because they are familiar with the latest 
mobile technologies (Alafeef et al., 2011). These results have encouraged the banking sector to target younger cohorts. However, contradicting results were noted by Mirza et al. (2009), who found that age does not have a prominent influence on the adoption of mobile banking services, especially internet banking. Thus, age was found not to be a critical variable for banks that plan to offer internet banking, thereby indicating the prevailing contradiction in the results, which justifies the need for a further investigation into the relationship from the under-researched region of East Africa. Based on these findings and DIT, which further states that early adopters are usually younger than late adopters, we assert that:

H4: Increased age is negatively associated with the adoption of mobile banking.

\section{METHODOLOGY}

\section{The context of the study}

Over the last three decades, Tanzania has undergone an economic transition aimed at promoting a market-driven economy. One of the sectors that have undergone substantial reforms is the financial sector, which includes the banking industry and other financial institutions. The banking sector is made up of commercial banks, non-bank financial institutions, community banks, and microfinance companies (MFCs). There are currently 40 commercial banks in Tanzania. The Bank of Tanzania (BoT) is a regulatory authority for the banking sector.

Despite the increase in the number of banks and the expansion of the financial sector, formal financial institutions reach only $18.4 \%$ of the population. This low percentage indicates that, in the face of increasing competition in the financial industry, the demand for finance is still high because of the high financial exclusion rate (FSDT, 2017). Digital banking and the use of mobile phones is one way of increasing financial inclusion.

The statistics from the Tanzanian Communication Regulatory Authority (TCRA) show the number of mobile phone subscribers to be over 32 million. This means mobile banking is one of the most feasible ways of providing a mass-market alternative to branch banking in Tanzania (Masamila, 2014). Collaboration between mobile network providers and banks offering mobile financial services presents the potential to extend beyond traditional bank coverage to include rural areas, which are characterized by low population density and poor infrastructure. This potential implies that understanding 
individual characteristics and their influence on adopting mobile financial services is vital in this context as it sheds more light on how to promote financial inclusion.

\section{Data and sampling}

The target population for this study was customers of one of the largest banks in Tanzania as it was among the first banks to introduce mobile banking in the country. The bank has more than 200 branches spread throughout the country. Because it is one of the largest banks and the first to introduce mobile banking, it represented a unique case to study the adaptability of its customers, the majority of who use mobile phones and access bank services. Furthermore, the bank has over 40 branches in the largest city of Dar es Salaam. Three branches were selected to participate in this study. These branches were the largest in the city in terms of the number of customers served and their diversity.

We sampled a total of 450 customers from the three branches. The respondents were selected randomly based on convenient sampling, which involved the researchers selecting customers due to their willingness to participate or their availability at the bank's premises. The respondents were introduced to the study as they were waiting for banking services in the bank. Upon agreeing to participate in the study, they were recruited for a survey. This sampling procedure was suitable for recruiting customer respondents in the banking environment. Only customers aged 18 and over were accepted as participants.

The study applied self-administered questionnaires completed by the respondents who had agreed to participate. Whoever entered the banking hall and waited to be served was approached, and the researcher introduced the study and asked whether she or he would participate in the study and fill in the questionnaire. Each respondent was assured of anonymity and confidentiality of the information and told that filling in the questionnaire would not take much of their time. This preface encouraged honest responses and reduced respondents' tendency to give socially desirable answers.

\section{Variables}

The dependent variable was the adoption of mobile banking, which was measured using non-metric questions in order to ascertain respondents' adoption of mobile banking. It involved a four-point Likert scale that measured behavioural items ranging from 1 - never to 4 - daily. Based on the literature, seven common financial services were adopted to measure the adoption of 
mobile banking (Alalwan et al., 2015). These were checking their balance, downloading bank statements, paying bills, and transferring funds. In addition, the study featured four independent demographic variables, which were income level, gender, education, and age. Table 1 provides a definition and measurements of all the variables used in the study:

Table 1. Definition of variables

\begin{tabular}{ll}
\hline Dependent variable & Measure \\
\hline Mobile banking use per & Measured as 1 = never; $2=1-3$ times per week; 3 = 4-6 times \\
per week; 4 = daily
\end{tabular}

\section{Reliability and validity checks}

As a check for reliability and validity (Hair et al., 2008), the questionnaire was sent to three groups of experts for review and scrutiny, and whose comments and suggestions were incorporated. Secondly, a pilot test with 25 customers was conducted in one branch (non-participating branch), so as to get the views and ideas of customers on which areas were more critical, especially in relation to adopting mobile banking. Complex questions or items were noted and amended. The adapted results of the pilot were tested using Cronbach's alpha, which indicated an alpha value of 0.836 for the seven items measured, thus showing high internal consistency.

\section{Analysis techniques}

The data were cleaned to detect missing values, identify outliers, and prepare them for multivariate analysis. The unit of analysis was the individual customer. The number of questionnaires that were useful for further investigation was 
416 out of the 450 given to the respondents. Thus, 34 questionnaires were found to have incomplete responses and were rejected for further analysis. Descriptive statistics were used to analyze the data in order to describe and summarize them in a meaningful way. Categorical and scaled data were described using frequency and percentage tables. Furthermore, measures of kurtosis and skewness were used to describe the distribution of scaled data and further assess their adherence to normality.

Prior to multivariate analysis, we conducted a principal component analysis (PCA) of exploratory factor analysis (EFA) for the dependent variable "adoption" since it was measured using seven items, which was done to derive one dependent variable for inclusion in the regression analysis (Hair et al., 2008). Correlation analysis was also run for all variables included in the regression. This was done in order to pre-test the hypotheses and determine whether there were relationships among variables. Correlations also helped in the detection of multicollinearity among independent variables. For hypothesis testing, we ran an ordinary least square (OLS) regression analysis method, whereby all independent variables were tested together. To check for robustness, each independent variable was regressed with the dependent variable "adoption." The model for the OLS regression is as follows:

\section{Adoption $=$ constant $+\mathrm{b} 1$ income $+\mathrm{b} 2$ male $+\mathrm{b} 3$ education $-\mathrm{b} 4$ age $+\mathrm{E}$}

\section{FINDINGS}

\section{Demographic characteristics}

The respondents were well-distributed along the lines of age, sex, education, and income level. With regard to age, the average was 31 years. This age group comprises the majority of college/university students, young active workers in organizations, and entrepreneurs in Dar es Salaam city (Table 2). As indicated in the table, the majority of respondents were males (66.6\%), a detail which may be attributed to the fact that, in most cases, males are users of banks. This result could also be mean that women are still struggling to gain access to formal banking halls and services due to cultural dynamism (Naegels, Mori, \& D’Espallier, 2018). 
Table 2. Demographic characteristics and summary statistics

\begin{tabular}{lr}
\hline Characteristics & Statistics \\
\hline Average age (years) & 31.00 \\
Average income (TZS) & $618,961.54$ \\
\hline Gender & \\
\hline Female (\%) & 33.40 \\
Male (\%) & 66.60 \\
\hline Education attainment & \\
\hline Secondary and below (\%) & 57.40 \\
Above secondary - College/University (\%) & 42.60 \\
\hline Occupation & \\
\hline Self-employed (\%) & 54.60 \\
Employed (\%) & 29.60 \\
Farmers (\%) & 9.40 \\
Students (\%) & 6.40 \\
\hline
\end{tabular}

In terms of education, it can be seen that the majority had received a college/university education (42.6\%). Also, out of $57.4 \%$, (28.8\%) have secondary education. This result can be interpreted in three ways. First, because Dar es Salaam is the largest city in Tanzania, the majority of residents are composed of educated people who engage in different activities, a characteristic common to large cities where educated people tend to live because of the opportunities that exist (Glaeser, 1999). The literature further suggests that industrial agglomeration exists in cities because individuals learn from one another when they live and work in close proximity, and they also acquire skills by interacting with one another, and city areas increase the speed of these interactions (Glaeser, 1999). Secondly, since the data were obtained from the largest branches, it is possible that people accessing them are the elite, and that is why we have these results. Thirdly, the study is on banks, and there is evidence that due to education and exposure, elite people have more confidence in accessing banks than their counterparts. Nevertheless, some respondents had not received a formal education and were likely to be among those operating small businesses, as suggested by the literature (Mori, 2014).

The study also sought to establish the level of occupation of the customers, which was done in order to connect it with income level. The results show that $54.6 \%$ were self-employed, followed by those employed in various professions. The high percentage of employees also implies that most of them were likely to receive their salaries through and save their money in the bank, thereby 
forming a large part of the customer base. This trend also reflected their level of income as their average monthly income was TZS 618,961.54.

\section{Adoption of mobile banking}

This section presents the prevalence of different dimensions of the adoption of mobile banking. Table 3 presents the descriptive findings from the seven items or statements that gauged respondents' frequency of using mobile banking. According to the results, the overall mean score of three out of the seven statements examined is 2 , indicating that the respondents' frequency of using mobile banking suggested by these statements was, overall, once to three times a week. The respondents used mobile banking one to three times a week to check the balance in their bank accounts (mean 2.19, SD 0.736), transfer money (mean 2.17, SD 0.841), and buy airtime for their mobile phones (mean 2.05, SD 0.889). The respondents rarely used mobile banking to obtain bank statements, pay bills, or access other dealers' services, as the statements had mean values of less than 2 .

Table 3. Descriptive statistics for adoption of mobile banking $(n=416)$

\begin{tabular}{|c|c|c|c|c|}
\hline Using Mobile banking to: & Min* & Max* & Mean & SD \\
\hline Check my balance & 1.00 & 4.00 & 2.19 & 0.736 \\
\hline Download mini-statement & 1.00 & 4.00 & 1.93 & 0.805 \\
\hline $\begin{array}{l}\text { Pay bills, such as electricity, water bills, } \\
\text { etc. }\end{array}$ & 1.00 & 4.00 & 1.86 & 0.811 \\
\hline $\begin{array}{l}\text { Transfer funds from my account to } \\
\text { a telecom network, such as Tigo, } \\
\text { Vodacom, Airtel, etc. }\end{array}$ & 1.00 & 4.00 & 2.17 & 0.841 \\
\hline Buy airtime & 1.00 & 4.00 & 2.05 & 0.889 \\
\hline Access other dealers' services & 1.00 & 4.00 & 1.61 & 0.814 \\
\hline Pay for football matches & 1.00 & 3.00 & 1.36 & 0.518 \\
\hline
\end{tabular}

Notes: ${ }^{*} 1$ = never; 2 = 1-3 times a week; 3 = 4-6 times a week; 4 = daily.

Table 4 further depicts the percentage of each of the seven items measuring the adoption of mobile banking by the respondents. The findings show that the majority of respondents used mobile banking one to three times a week to check their balance, download a mini-statement, pay bills, transfer funds from their account to a mobile telecom network, and buy airtime. Using mobile banking to buy airtime seems to be the most prevalent, as 9.9\% do this daily, followed by checking their balance (8.7\%) and transferring funds from their account to a mobile telecom network (8.7\%). The fact that many customers transfer money from their account to either buy airtime or top 
up their mobile phone account (M-Pesa, etc.) implies that many customers prefer to keep their money in their phone rather than in the bank. This behavior in line with the findings of Finscope (2017), which found that only $17 \%$ have active bank accounts while $43 \%$ have mobile payment accounts. It also means that people prefer their money to be in a mobile account rather than a bank account, perhaps because it is easier to obtain cash from their mobile account than from a bank account due to the availability of agencies. It is also possible that the charges are less expensive when their money is on a mobile phone than in the bank. The banks need to look into in detail and find ways of collaborating with MNOs for the benefit of both.

In addition, the use of sim banking to pay for football matches is rarely used as about $66 \%$ never used this service, and only $32 \%$ used it one to three times a week. This could mean that not many people who are football fans were in our database.

Table 4. Descriptive statistics (percentages) for adoption of mobile banking (in \%)

\begin{tabular}{lrrrr}
\hline Items - using mobile banking to: & $\mathbf{1}$ & $\mathbf{2}$ & $\mathbf{3}$ & $\mathbf{4}$ \\
\hline & Never & $\mathbf{1 - 3}$ times & 4-6 times & Daily \\
& & & & \\
\hline Check my balance & 10.80 & 68.50 & 12.00 & 8.70 \\
Download mini-statement & 30.00 & 52.90 & 11.10 & 6.00 \\
Pay bills, such as electricity, water bills, etc. & 35.60 & 48.30 & 10.80 & 5.30 \\
Transfer funds from my account to a mobile & 19.70 & 52.60 & 19.00 & 8.70 \\
telecom network (Tigo, Vodacom, Airtel) & & & & \\
Buy airtime & 27.20 & 50.50 & 12.50 & 9.90 \\
Access other dealers' services & 55.50 & 32.90 & 6.70 & 4.80 \\
Pay for football matches & 66.30 & 31.70 & 1.90 & 0.00 \\
\hline
\end{tabular}

\section{Factor analysis}

As explained earlier, because the dependent variable was measured using seven items, a principal component analysis (PCA) of exploratory factor analysis (EFA) was conducted in order to test whether correlating items could be summarized as an 'adoption' factor with a minimum loss of information (Hair et al., 2008). PCA was also employed to reduce the information contained in a number of measurement items to a smaller set of items organized into factors. PCA considered a total of 7 items measuring the construct of adoption of mobile banking. Prior to the analysis, the suitability of items for PCA was checked and all items met the normality requirement. Afterwards, PCA varimax rotation was performed (Hair et al., 2008). The eigenvalue for 
item 7 on "the use of mobile banking to pay for football matches" had a value of less than 0.5 and was therefore eliminated from further analysis. Using the latent root criterion with a cut-off value of 1.0 for the eigenvalue, the final run with 6 items resulted in a one-factor solution accounting for $54.54 \%$ of total variance. Thus, the one-factor solution representing adoption of mobile banking, which was moreover consistent with the literature, was retained (Table 5). From this, we scaled (found the average of the six items) and formulated one variable for "adoption."

Table 5. Rotated factor matrix results

\begin{tabular}{lrr}
\hline Factor: Adoption & Factor loadings & Communality \\
\hline Check my balance & 0.742 & 0.551 \\
Download mini-statement & 0.748 & 0.559 \\
Pay bills, such as electricity, water bills, etc. & 0.790 & 0.624 \\
Transfer funds from my account to a mobile & 0.746 & 0.556 \\
telecom network & & \\
Buy airtime & 0.744 & 0.553 \\
Access other dealers' services & 0.655 & 0.550 \\
Variance & & $\mathbf{5 4 . 5 4 4}$ \\
\hline
\end{tabular}

\section{Correlation results}

Looking at the correlation among the independent variables, we see that gender is significantly correlated with income (coeff. 0.147) and education with income (coeff. 0.281). The significance of these is not of a high magnitude to attract multicollinearity. In terms of the correlation between the dependent and independent variables, the table shows that adoption is significantly and positively correlated with education (coeff. 0.216 ) and income (coeff. 0.356). Gender and age were also positively correlated with the adoption of mobile banking but were not statistically significant. Overall, the correlations, except for age, correspond to the theorized relationships in the conceptual framework and hypotheses, thus indicating initial support for the hypotheses and no problem with nomological validity (Hair et al., 2014). 
Table 6. Correlations results

\begin{tabular}{lllll}
\hline & Adoption & Gender & Age & Education \\
\hline Adoption & 1.000 & & & \\
Gender & 0.082 & 1.000 & & \\
Age & 0.045 & 0.027 & 1.000 & \\
Education & $0.216^{* *}$ & 0.064 & -0.051 & 1.000 \\
Income & $0.356^{* *}$ & $0.147^{* *}$ & 0.078 & $0.281^{* *}$ \\
\hline Note: ${ }^{* *}$ correlation is significant at the 0.01 level (2-tailed). & &
\end{tabular}

\section{OLS regression results and discussion}

Hypothesis 1 tested the positive association between customers' income level and adoption of mobile banking. As indicated in Table 7, this hypothesis is supported (coeff. $=0.313, p<0.001$ ). This suggests that the higher the income, the more likely the customer will adopt mobile banking. Customers' level of income was measured by referring to their income per month. From their income, it seems customers are more likely to use mobile banking to transfer funds from their bank account to their mobile phone network and to buy airtime for their other needs, including business. They are also likely to be salaried employees who often check the balance in their bank account. Alternatively, it can be argued that those engaged in business are often risk-takers. As regards the notion of risk, these customers do not perceive mobile banking to be risky, unlike other customers (Makanyeza, 2017). Table 7 presents the regression results for each hypothesis tested.

Table 7. OLS regression results with adopt as a dependent variable

\begin{tabular}{lll}
\hline & Coefficient & Std. error \\
\hline Level of income & $0.313^{* *}$ & 0.000 \\
Age & 0.028 & 0.003 \\
Gender & 0.029 & 0.061 \\
Education attainment & $0.128^{* *}$ & 0.029 \\
Adjusted r-square & 0.134 & \\
Durbin Watson & 1.683 & \\
\hline Note: ${ }^{* *}$ coefficient is significant at the 0.01 level (2-tailed).
\end{tabular}

Another interpretation of this finding is that using mobile banking often requires one to have a mobile phone. Moreover, one must have funds in the bank account. Thus, those with higher incomes are more likely to find it easy to use mobile banking frequently. The findings of this study also showed that income level is the strongest factor among the other demographic variables 
considered. This corroborates previous research, which argued that income level is an important factor that has a strong influence on adoption level (Alafeef et al., 2011; Harma \& Dubey, 2009; Mirza et al., 2009; Swai, 2015). However, it contradicts a few studies, such as by Laukkanen and Pasanen (2008), who found that income does not predict the use of mobile banking. The finding also supports Roger's Diffusion of Innovation Theory by showing how adoption can be influenced by high income.

Hypothesis 2 stated that male customers are positively associated with the adoption of mobile banking. As indicated in Table 7, this hypothesis is supported by indicating the presence of a positive relationship, $b=0.029$, but with no statistical significance $(p>0.05)$. Although the results were not statistically significant, they still suggest that male customers are positively associated with the adoption of mobile banking. Borrowing Alafeef et al.'s (2011) reasoning, males are more willing than women to take risks to try out any new technological product. This could be the case in Tanzania where, after all, mobile banking technology was introduced no more than five years ago. However, a more logical reason is that this may be due to the cultural context of Tanzania. It is well known that longstanding cultural traditions and entrenched social norms distinctly define gender roles in the country (Krogh et al., 2009). Given the fact that it requires some kind of income from business or a salary from employment to use mobile banking, women are less likely to use it. Using similar reasoning, the cultural traditions and norms of Tanzanian society have, in the past, also limited women from owning smart mobile phones.

The fact that the results are statistically insignificant could also mean that there is not enough evidence to confirm the positive relationship. Given the high level of exposure to the modern way of life, women in these areas are more likely to own a mobile phone and try using new technologies, which might partly explain the insignificant results, a fact perhaps not unique to this study. A previous study by DeBaillon and Rockwell (2005) also found an insignificant relationship between gender and the adoption of internet banking. Nevertheless, other prior studies found a positive and significant relationship (see Laforet \& Li, 2005; Venkatesh \& Morris, 2000; Monsuwe et al., 2004; Mirza et al., 2009; Sulaiman et al., 2007). Most of these studies were conducted in the Arab world, where gender role and division is prominent, and men are more likely to be engaged in the workforce and be familiar with technological advances than women, who spend most of their time at home (Mirza et al., 2009). Overall, the findings of this study agree with past research on the argument that male customers are positively associated with the adoption of new technologies, including mobile banking.

Hypothesis 3 was set to test the association between customers' education attainment and adoption of mobile banking. The results provide 
support for it (coeff. $=0.128, p<0.01$ ). These results suggest that the higher the customer's education level, the more likely she or he will adopt mobile banking. It is logical to argue from the exposure framework that those who are more educated, that is those who have received a higher level of education, are more likely to be exposed to new technologies due to their training and peer groups at colleges and universities. This result echoes Hill's (1998) argument that most schools, colleges, and universities today teach computer skills as a compulsory part of the curriculum. Customers are, therefore, more exposed to new technologies and are likely to adopt mobile banking. People who are more educated are also more likely to accept the risks associated with the use of new technologies for the reason of personal advancement. Alternatively, people with a higher education level are believed to be rational and would thus choose a way of doing something that costs less. For instance, it would cost a person more to go to a bank to enquire about her or his balance or obtain a statement than to use mobile banking. With this rational thinking, a more educated person would rather use mobile banking than those who are less educated in order to save time in terms of visiting a branch and money spent on a busfare for that purpose.

Burgess's (1986) logic can also be useful for explaining the positive relationship between the level of education and the adoption of mobile banking in the Tanzanian context. It is common knowledge that individuals with more years of education are more likely to be in high-status occupations with a higher income. They are more likely, therefore, to afford the costs involved and, due to their status, adopt new technology. The findings of this study support past research, like Hill (1998), Harma and Dubey (2009), Ahmed et al. (2013), and Sulaiman et al. (2007).

Hypothesis 4 examined the negative association between age and the adoption of mobile banking. The result was not statistically significant. The results in Table 7 further show the statistical presence of a positive relationship between age and the adoption of mobile banking ( $b=0.028)$, but it is not statistically significant $(p>0.05)$. This suggests that the older a customer is, the more likely she or he will adopt mobile banking. However, this relationship was not statistically significant. The dominant argument in the literature, and thus the hypothesis adopted in this study, is that there is a negative relationship between increased age and the adoption of mobile banking (Matilla et al., 2003; Harma \& Dubey, 2009), specifically, younger people are more likely to adopt mobile banking than older ones. In Tanzania, similar to Mirza et al. (2009), this study shows that older age is important though not significant. Furthermore, the likelihood that older people may prefer mobile banking is explained by the notion of distance and accessibility. It is known that the distance between where banks are located and where 
customers are, makes it hard for older people to access them. Therefore, they would probably prefer to do some banking activities, such as buying airtime and checking their balance using mobile banking, rather than having to go to the bank, which can be difficult and tiring.

Table 8 provides a summary of our results by showing that two hypotheses (one and three) were supported, according to our expectations. Hypothesis two was not supported, and hypothesis four was not supported but was positively significant.

Table 8. Summary of the results

\begin{tabular}{|c|c|c|}
\hline \multicolumn{2}{|c|}{ Hypotheses } & \multirow{2}{*}{$\begin{array}{l}\text { Results } \\
\text { Supported at } \\
p<0.001\end{array}$} \\
\hline H1 & $\begin{array}{l}\text { There is a positive association between customers' } \\
\text { income level and adoption of mobile banking. }\end{array}$ & \\
\hline $\mathrm{H} 2$ & $\begin{array}{l}\text { Male customers are positively associated with the } \\
\text { adoption of mobile banking. }\end{array}$ & Not supported \\
\hline H3 & $\begin{array}{l}\text { There is a positive relationship between education } \\
\text { attainment and adoption of mobile banking. }\end{array}$ & Supported at $p<0.01$ \\
\hline H4 & $\begin{array}{l}\text { There is a negative association between age and } \\
\text { adoption of mobile banking. }\end{array}$ & Not supported \\
\hline
\end{tabular}

\section{CONCLUSIONS AND IMPLICATIONS}

The main objective of this study was to examine the influence of demographic variables on customers' adoption of mobile banking. Four hypotheses were formulated, and data from 416 bank customers were used to test the hypotheses by employing an OLS regression technique. The results revealed that there is a positive and statistically significant relationship between income level and adoption of mobile banking. Indeed, the higher the income, the more likely a person will adopt mobile banking. The results also revealed that there is a positive relationship between education level and adoption of mobile banking. However, although it was revealed that age was not important in determining the adoption of mobile banking, it was found to have a positive relationship with the adoption of mobile banking. Thus, given the accessibility of this banking service and infrastructure, the older a person gets, the more likely she or he will use mobile banking.

The overall conclusion is that the adoption of mobile banking is best viewed from the rational-thinking perspective that people with a higher income and higher education level are more likely to find mobile banking convenient and easy to use than those with a lower income and lower 
level of education. For people on a higher income, it is probably cheaper, more convenient and rational to use mobile banking than physically visiting the bank to access services such as buying airtime, checking a balance, or obtaining a statement. On the other hand, although gender and age may not be important in determining the adoption of mobile banking due to insignificant results, they show an interesting trend. With particular reference to age, older people are more likely to adopt mobile banking, perhaps due to its accessibility in the Tanzanian context.

This paper has made important contributions to the literature on the adoption of new technologies in the banking industry. First, it has shown the relevance of Diffusion of Innovation Theory (DIT) in explaining the adoption of new technologies, especially mobile banking services, in the context of sub-Saharan Africa, and especially in Tanzania, where it has rarely (if ever) been utilized. Second, it has contributed to providing an understanding of and empirical evidence on the controversial link between demographic variables, such as level of income, education attainment, sex and age, and the adoption of mobile banking. Third, it has contributed to providing an understanding of the adoption of mobile banking from the point-of-view of customers in the ignored context of sub-Saharan Africa, especially Tanzania.

Past research has paid attention to the determinants of adoption of new technologies using socio-psychological frameworks, such as the theory of planned behavior, social exchange theory, and the technology adoption model. They argued that perceived risk, trust, convenience, comparative advantage, expected performance, reduced effort, social influence, price, value, and attitudes relate to the adoption of mobile banking in general and mobile banking in particular (Venkatesh et al., 2003; Curran \& Meuter, 2005, Swai, 2015; Munisi, 2015; Yu, 2012; Zhou et al., 2010).

Apart from these factors, past research has also acknowledged the importance of situational factors, especially the demographic characteristics of individuals, such as income level, sex, education attainment and age in explaining adoption (Alafeef et al., 2011; Bhatt \& Bhatt, 2016; Venkatesh et al., 2003; Curran \& Meuter, 2005). However, research has produced mixed and inconsistent results regarding the relationship between these demographic factors and the adoption of mobile banking. For example, while it is has become common knowledge that income positively relates to the adoption of new technology, Laukkanen and Pasanen (2008) found that income does not predict the use of mobile banking. Similarly, while Sulaiman et al. (2007), Harma and Dubey (2009) and Alafeef et al. (2011) found a significant relationship between age and the adoption of new technology, Mirza et al. (2009) found no significant relationship. Studies have also argued that education level relates positively to the adoption of new 
technology, but in a poor country such as Tanzania, there are few individuals with a university degree. In this context, potential users of mobile banking might have secondary education and above. This is due to the relatively low level of education in sub-Saharan Africa compared to developed regions. Thus, there is a need for research to focus on cases in sub-Saharan Africa and Tanzania in particular. In addition, although studies (e.g. Alafeef et al., 2011) found a significant relationship between gender and adoption, DeBaillon and Rockwell (2005) found an insignificant relationship.

Moreover, this relationship remains blurred in sub-Saharan Africa where gender is known to determine how males and females engage with technological advances. This study contributed to this debate and body of knowledge by examining the influence of demographic variables on the adoption of mobile banking, drawing only on customers of a leading bank in Tanzania. In the Tanzanian context, the adoption of mobile banking is best viewed from the rational-thinking perspective. Customers with a higher income and higher education level are more likely to adopt mobile banking than those with a relatively low income and low level of education.

The study has several practical implications. The results alert Tanzanian banks to the current state of their customers' adoption of mobile banking services. The descriptive results of the adoption of mobile banking revealed that the majority of respondents used mobile banking one to three times a week to check their balance, download mini-statement, pay bills, transfer funds from their account to a telecom network and buy airtime. This obviously suggests that the majority of the respondents seem to be motivated to use mobile banking. It was observed that education plays a significant role in determining the adoption of mobile banking as it exposes people to technology and increases their confidence in using it. Bank managers should, therefore, expose customers to mobile banking technology either when they visit the bank or at their premises. This would help increase the number of users and likely the frequency of mobile banking as a result. It was also established that income significantly relates to the adoption of mobile banking, which suggests that promotional programs should focus on potential users, that is, those with a higher income, as this would lead to more customers using mobile banking services.

Despite the interesting findings and contributions, caution should be exercised when interpreting the results in the broader context because of three limitations. First, the study focused on customers in the largest city of Tanzania; if conducted in other towns, it might not produce similar results. Although the findings of this study can be generalizable to other banks, future research could use a larger sample. It would also be worthwhile for future studies to incorporate bank branches located in rural areas where 
extreme poverty dominates and strict traditional gender norms that overlook women in terms of technological advances are still in practice. Perhaps in these localities, the research will reveal the effect of culturally-conditioned gender roles and expectations on the adoption of mobile banking.

Furthermore, this study is limited in that it does not utilize all elements of the Diffusion of Innovations Theory. Other aspects such as Personality Variables (i.e., dogmatism, rationality, and high aspirations), Communication Behavior (social participation, change agent contact, and mass media exposure) and Innovation Characteristics are not included, and these are potential areas for further examination. In addition, qualitative research using in-depth interviews and focus group discussions would enrich our understanding of the contextual reality underlying the effects of sex and especially age (which has shown a contradictory positive relationship) on the adoption of mobile banking.

\section{References}

Abdinoor, A., \& Mbamba, U. O. (2017). Factor influencing consumers' adoption of mobile financial services in Tanzania. Cogent Business \& Management, 4(1), 1-19. http://doi.org/10.1080/23311975.2017.1392273

Ahmed, A. M., Moreton, R., Mehdi, Q. H., \& Elmaghraby, A. (2013). E-government services challenges and opportunities for developing countries: The case of Libya. Paper presented at the 2013 Second International Conference on Informatics \& Applications (ICIA). Retrieved from https://www.academia. edu/24237882/E-Government_Services_Challenges_and_Opportunities_ for_Developing_Countries_The_Case_of_Libya

Alafeef, M., Singh, D., \& Ahmad, K. (2011). Influence of demographic factors on the adoption level of mobile banking applications in Jordan. Research Journal of Applied Sciences, 6(6), 373-377. http://doi.org/10.3923/ rjasci.2011.373.377

Alalwan, A.A., Rana, N.P., Dwivedi, Y.K., Lai, B., \& Williams, M.D. (2015). Adoption of mobile banking in Jordan: Exploring demographic differences on customers' perceptions. IFIP International Federation for Information Processing, 9373, 13-23. http://doi.org/10.1007/978-3-319-25013-7_2

Ajide, F.M. (2016). Financial innovationandsustainabledevelopmentinselected countries in West Africa. Journal of Entrepreneurship, Management and Innovation, 12(3), 85-111. https://doi.org/10.7341/20161234

Burgess, R. (1986). Key Variables in Social Investigation. London: Routledge. https://doi.org/10.4324/9781351170000

Bhatt, A., \& Bhatt, S. (2016). Factors affecting customers' adoption of mobile banking services. Journal of Internet Bank Commerce, 21. Retrieved from http://www.icommercecentral.com/open-access/factors-affectingcustomers-adoption-of-mobile-banking-services. php?aid=70189 
Cruz, P., Neto, L., Gallego, P., \& Laukkanen, T. (2010). Mobile banking rollout in emerging markets. Evidence from Brazil. The International Journal of Bank Marketing, 28(10), 342-371. http://doi. org/10.1108/02652321011064881

Curran, J.M. \& Meuter, M.L. (2005). Self-service technology adoption: Comparing three technologies. Journal of Services Marketing, 19,(2), 103-113. http://dx.doi.org/10.1108/08876040510591411

DeBaillon, L., \& Rockwell, P. (2005). Gender and student-status differences in cellular telephone use. International Journal of Mobile Communication, 3(1), 82-98. http://doi.org/10.1504/IJMC.2005.005876

Glaeser, E.L. (1999). Learning in cities. Journal of Urban Economics, 46(2), 254-277. https://doi.org/10.1006/juec.1998.2121

Golejewska, A. (2018). Innovativeness of enterprises in Poland in a regional context. Journal of Management, Entrepreneurship and Innovation. 14(1), 29-44. https://doi.org/10.7341/20181412

Gosavi, A. (2017). Use of the Internet and its impact on productivity and sales growth in female-owned firms: Evidence from India. Journal of Entrepreneurship, Management and Innovation 13(2), 155-178. https:// doi.org/10.7341/20171327

Harma, M.K., \& Dubey, R. (2009). Prospects of technological advancements in banking sector using mobile banking and position of India. Proceedings of the International Association of Computer Science and Information Technology Spring Conference (pp. 291-295). Retrieved from https:// ieeexplore.ieee.org/abstract/document/5169360

Hair, J., Black, B., Babin, B., Anderson, R., \& Tatham, R. (2008). Multivariate Data Analysis New Delhi: Prentice Hall.

Hill, A.M.(1998). Problem solving in real-life contexts: An alternative for design in technology education. International Journal of Technology and Design Education. 8(1), 203-220. https://doi.org/10.1023/A:1008854926028

Kolodinsky, M.J., Hogarth, M., \& Hilgert, A.M. (2004). The adoption of electronic banking technologies by US consumers. International Journal of Bank Marketing, 22(4), 238-259. http://doi.org/10.1108/02652320410542536

Krogh, E., Hansen, T.N., Wendt, S., \& Elkjaer, M. (2009). Promoting employment for women as a strategy for poverty reduction. Organization for Economic Cooperation and Development (OECD). Retrieved from http://www. oecd.org/greengrowth/green-development/43514554.pdf

Laforet, S., \& Li, X.Y. (2005). Consumers' attitudes towards online and mobile banking in China. International Journal of Bank Marketing, 3(5), 362-380. http://doi.org/10.1108/02652320510629250

Laukkanen, T., \& Pasanen, M. (2008). Mobile banking innovators and early adopters: How they differ from other online users. Journal of Financial Service Marketing, 13(2), 86-94. http://doi.org/10.1057/palgrave. fsm. 4760077

Lee, K.S., Lee, H.S., \& Kim, S.Y. (2007). Factors influencing the adoption behaviour of mobile banking: A South Korean perspective. Journal of Internet Banking 
and Commerce, 12,(2). Retrieved from http://www.icommercecentral. com/open-access/factors-influencing-the-adoption-behavior-of-mobilebanking-a-south-korean-perspective.php?aid=38487

Lohse, G.L., Bellman, S., \& Johnson, E.J. (2000). Consumer buying behaviour on the Internet:Findings from panel data.Journal of Interactive Market, 14(1), 15-29. https://doi.org/10.1002/(SICl)1520-6653(200024)14:1<15::AIDDIR2>3.0.CO;2-C

Makanyeza, C. (2017). Determinants of consumers' intention to adopt mobile banking services in Zimbabwe. International Journal of Bank Marketing, 35(6), 997-1017. http://doi.org/10.1108/IJBM-07-2016-0099

Masamila, B. (2014). State of mobile banking in Tanzania and security issues. International Journal of Network Security and its Applications, 6(4), 5364. http://doi.org/10.5121/ijnsa.2014.6405

Mattila, M., Karjaluoto, H., \& Pento, T. (2003). Internet banking adoption among mature customers: Early majority or laggards?. Journal of Services Marketing,17(5),514-528. https://doi.org/10.1108/08876040310486294

Mattila, K. (2003). Factors affecting the adoption of mobile banking services. Journal of Internet Banking Commerce, 8, 14-15. Retrieved from http:// www.icommercecentral.com/open-access/factors-affecting-theadoption-of-mobile-banking-services. php?aid=38725

Mirza, A.P., Beheshti, M.T.H., Wallstrom, A., \& Mirza, O.P. (2009). Adoption of internet banking by Iranian consumers: An empirical investigation. Journal of Applied Sciences, 9(14), 2567-2575. http://doi.org/10.3923/ jas.2009.2567.2575

Monsuwe, T.P., Dellaert, B.G.C., \& de Ruyter, K. (2004). What drives consumers to shop online? A literature review. International Journal of Service Industry Management, 15(1), 102-121. https://doi. org $/ 10.1108 / 09564230410523358$

Mori, N. (2014). Women entrepreneurship development in Tanzania. Retrieved from https://www.ilo.org/wcmsp5/groups/public/---ed_emp/---emp_ ent/---ifp_seed/documents/publication/wcms_360426.pdf.

Munisi, R. (2015). Attitudinal factors and adoption of e-money services in Tanzania: A case of Ilala District's SMEs in Dar es Salaam. Unpublished MBA Dissertation, University of Dar es Salaam, Dar es Salaam.

Naegels, V., Mori, N., \& D'Espallier, B. (2018). An institutional view on access to finance by Tanzanian women-owned enterprises. Venture Capital, 20(2), 191-210. https://doi.org/10.1080/13691066.2017.1358927

Rambocas, M., \& Arjoon, S. (2012). Using diffusion of innovation theory to model customer loyalty for internet banking: A TT millennial perspective. International Journal of Business and Commerce, 1(8), 1-14.

Reem, R., \& Jawdat, A. (2018). A model of mobile payment usage among Arab consumers. International Journal of Bank Marketing, 36(7), 1213-1234, https://doi.org/10.1108/IJBM-05-2017-0080

Rogers, E. (1995). Diffusion of Innovations ( $3^{\text {rd }}$ ed.). New York: Free Press. Rogers, E. (2003). Diffusion of Innovations ( $5^{\text {th }}$ ed.). New York: Free Press. 
Singh, S., \& Srivastava, R. K. (2018). Predicting the intention to use mobile banking in India. International Journal of Bank Marketing, 36(2), 357 378. https://doi.org/10.1108/IJBM-12-2016-0186

Sulaiman, A., Jaafar, N.I., \& Mohezar, S. (2007). An overview of mobile banking adoption among the urban community. International Journal of Mobile Communications, 5,(2), 157-168. https://doi.org/10.1504/ IJMC.2007.011814

Swai, F.A. (2015). Factors influencing customers' adoption and actual use of mobile phone payment services in Tanzania. Unpublished MBA Dissertation, University of Dar es Salaam, Dar es Salaam.

Van de Wijngaert, L., \& Bouwman, H. (2009). Would you share? Predicting the potential use of a new technology. Telematics and Informatics, 26(1), 85-102. https://doi.org/10.1016/j.tele.2008.01.002

Venkatesh, V., \& Morris, M. (2000). A longitudinal field investigation of gender differences in individual technology adoption decision-making processes. Organizational Behavior and Human Decision Processes, 83(1), 33-60.

Venkatesh, V., Morris, M.G., Davis, G.B., \& Davis, F.D. (2003). User acceptance of information technology: Toward a unified view. MIS Quarterly, 27(3), 425-478. http://doi.org/10.2307/30036540

Yu, C.S. (2012). Factors affecting individuals to adopt mobile banking: Empirical evidence from the UTAUT Model. Journal of Electronic Commerce Research, 13(2), 104-121.

Zhou, T., Lu, Y., \& Wang, B. (2010). Integrating TTF and UTAUT to explain mobile banking user adoption. Computing Human Behaviour, 26(4), 760-767. http://doi.org/10.1016/j.chb.2010.01.01

\section{Abstrakt}

Głównym celem tych badań było zbadanie wpływu czynników demograficznych na przyjęcie innowacyjnych usług bankowości mobilnej w Tanzanii. Wykorzystano teorię dyfuzji innowacji Rogersa (DIT), aby ustalić znaczenie czynników demograficznych zależnych od sytuacji. Ankieta została przeprowadzona z 416 klientami wiodqcego ban$k u$ w Tanzanii. W badaniu zastosowano kwestionariusze wypełniane przez respondentów, którzy zgodzili się wziqć udział w badaniu. Dane analizowano przy użyciu kombinacji analiz opisowych i wielowymiarowych. Wyniki opisowe ujawniły, że większość respondentów korzystała z bankowości mobilnej raz do trzech razy w tygodniu, aby sprawdzić saldo, pobrać mini wycigg, zapłacić różne rachunki, przelać środki ze swojego rachunku do mobilnej sieci telekomunikacyjnej i kupić czas antenowy. Wyniki regresji wykazały ponadto pozytywny i znaczqcy zwiqzek między poziomem dochodów a poziomem wykształcenia z jednej strony a przyjęciem bankowości mobilnej $z$ drugiej. Badanie dowodzi, że potrzebne sq praktyki promocyjne i kampanie uświadamiajqce, aby uchwycić profile demograficzne klientów i zachęcić ich do korzystania z bankowości mobilnej. Badanie wykazało znaczenie zastosowania teorii sytuacyjnej do przyjęcia innowacyjnych technologii w zakresie usług bankowych w Tanzanii. Po- 
szerza także nasze rozumienie znaczenia czynników demograficznych, na które nie zwracano uwagi w dominujqcych teoriach społeczno-psychologicznych.

Słowa kluczowe: bankowość mobilna, Tanzania, poziom dochodów, płeć, wiek, wykształcenie

\section{Biographical notes}

Neema Mori is an Associate Professor at the Department of Finance at the University of Dar es Salaam Business School. She holds a Ph.D. in International Business from the University of Agder, Norway; MBA (Finance) and BCom (Finance) from the University of Dar es Salaam, Tanzania. She has over fourteen years of experience in teaching, researching and consulting in areas of corporate finance, small business finance, corporate governance, microfinance, and entrepreneurship.

Rosallia Mlambiti works with CRDB Bank Plc as one of its Customer Service Managers. She holds a Master of Business Administration (MBA) from the University of Dar es Salaam, Tanzania. She has vast experience in banking and customer service.

\section{Conflicts of interest}

The authors declare no conflict of interest.

\section{Citation (APA Style)}

Mori, N., \& Mlambiti, R. (2020). Determinants of customers' adoption of mobile banking in Tanzania: Further evidence from a diffusion of innovation theory. Journal of Entrepreneurship, Management and Innovation, 16(2), 203-229. https://doi.org/10.7341/20201627 